\title{
PEMETAAN AIR TANAH PADA LAHAN KERING DI RT 05 DESA MUARO PIJOAN MENGGUNAKAN METODE GEOLISTRIK KONFIGURASI WENNER
}

\author{
Eka Nurshafni", Faizar Farid, Samsidar, Linda Handayani \\ Prodi Fisika, Fakultas Sains dan Teknologi, Universitas Jambi \\ *E-mail korespondensi: ekanurshafni@gmail.com
}

\begin{abstract}
The Study has been done using the geoelectric wenner configuration method in Muaro Pijoan Village, District of Jambi Luar Kota, Muaro Jambi Regency. The purpose of this study were to map the resistivity and determine the ground water position in Muaro Pijoan Village. The study area is divided into 5 tracks, 2 tracks along 100 meters and 3 tracks along 200 meters. Tracks with length 100 meters has space 5 meters and the track with length 200 meters has space of 10 meters. The value obtained from the measurement is the current and potential values, the value is used to obtain the apparent resistivity. The apparent resistivity value is then inverted using Res2Dinv software into 2 dimensional form. The inversion results in 3 cross-sectional resistivity imaged with color and each color indicates a sunder ground resistivity value. Based on the rock resistivity table, ground water has a resistivity value between 30-100 .m. From the cross-sectional resistivity it is found that all tracks have a potential ground water content and the location varies from 2.5 to 34.6 meters below the soil surface. The largest groundwater potential is on track 3 and the smallest is on track 5. Based on its groundwater position in Muaro Pijoan Village includes shallow groundwater.
\end{abstract}

Keywords: Geoelectrical method, wenner configuration, ground water

\begin{abstract}
ABSTRAK
Telah dilakukan penelitian menggunakan metode geolistrik konfigurasi wenner di Desa Muaro Pijoan, Kecamatan Jambi Luar Kota, Kabupaten Muaro Jambi. Tujuan dari penelitian ini adalah untuk memetakan resistivitas dan menentukan posisi air tanah di Desa Muaro Pijoan. Pada penelitian ini, daerah penelitian dibagi menjadi 5 lintasan, 2 lintasan memiliki panjang 100 meter dan 3 lintasan memiliki panjang 200 meter. Lintasan dengan panjang 100 meter memiliki spasi 5 meter sedangkan lintasan dengan panjang 200 meter memiliki spasi 10 meter. Nilai yang didapatkan dari pengukuran berupa nilai arus dan potensial, nilai tersebut digunakan untuk mendapatkan nilai resistivitas sети. Nilai resistivitas sети keтиdian diinversi menggunakan software Res2Dinv menjadi bentuk 2 dimensi. Hasil inversi berupa 3 penampang resistivitas yang dicitrakan dengan warna dan masing-masing warna menunjukkan nilai resistivitas bawah permukaan. Berdasarkan tabel resistivitas batuan, air tanah memiliki nilai resistivitas antara 30-100 .m. Dari penampang resistivitas didapatkan bahwa semua lintasan mempunyai kandungan air tanah yang potensi dan letaknya bervariasi mulai dari 2,5-34,6 meter dibawah permukaan tanah. Potensi air tanah terbesar berada pada lintasan 3 dan yang terkecil berada pada lintasan 5. Berdasarkan kedudukannya air tanah di Desa Muaro Pijoan termasuk air tanah dangkal.
\end{abstract}

Kata kunci: metode geolistrik, konfigurasi wenner, air tanah

\section{PENDAHULUAN}

Air tanah merupakan air yang terdapat pada ruang antar butir batuan atau celah-celah batuan. Menurut [1] air tanah tersimpan dalam suatu wadah (akuifer), yaitu formasi geologi yang memiliki kemampuan untuk menyimpan dan meloloskan air dalam jumlah yang cukup.
Terbentuknya air tanah tidak lepas dari siklus hidrologi.Siklus hidrologi adalah rangkaian peristiwa yang terjadi pada air, mulai dari air jatuh ke bumi (hujan) hingga menguap ke udara untuk kemudian jatuh kembali ke bumi yang merupakan konsep dasar keseimbangan 
air secara global. Siklus hidrologi akan terus berlangsung secara kontinu [2].

Lapisan batuan di bawah permukaan tanah memiliki sifat lolos air yang disebut permeabel misalnya seperti kerikil, pasir, batu apung, dan batuan gamping yang memiliki pori pada permukaannyadan lapisan yang tidak lolos air (kedap air) disebut impermeabel misalnya terdiri dari granit, batuan beku, metamorf, napal dan tanah liat (lempung) [2].

Air tanah memiliki 2 keadaan di bawah permukaan, yaitu air tanah bebas dan tertekan. Air tanah dalam akuifer yang tidak tertutup dengan lapisan impermeabel disebut air tanah bebas atau air tak tertekan. Sedangkan air tanah dalam akuifer yang tertutup dengan lapisan impermeabel mendapat tekanan disebut air tertekan [3]. Ditinjau dari kedudukannya terhadap permukaan, air tanah terbagi menjadi, air tanah dangkal dan air tanah dalam. Air tanah dangkal (freatis) berasosiasi dengan air tanah bebas yang terdapat dalam akuifer hingga kedalaman $40 \mathrm{~m}$. Air tanah dalam (artesis) berasosiasi dengan air tanah tertekan, yang tersimpan pada kedalaman lebih dari 40 $\mathrm{m}[2]$.

Keberadaan air tanah dapat diketahui dengan melakukan survei menggunakan metode geolistrik. Metode geolistrik merupakan salah satu metode dalam geofisika yang mempelajari sifat aliran listrik bawah permukaan dan bagaimana cara mendeteksinya di permukaan bumi. Terdapat beberapa jenis metode geolistrik salah satunya adalah metode geolistrik resistivitas (tahanan jenis) [4]. Cara penyusunan elektroda dalam metode geolistrik resistivitas yang disebut juga konfigurasi elektroda. Konfigurasi yang digunakan dalam penelitian adalah konfigurasi wenner. Susunan elektroda pada konfigurasi wenner yaitu $\mathrm{C}_{1}(\mathrm{~A}), \mathrm{P}_{1}(\mathrm{M}), \mathrm{P}_{2}(\mathrm{~N})$, dan $\mathrm{C}_{2}(\mathrm{~B})$ dengan jarak antar elektroda sama panjang [5].

Sebelumnya pernah dilakukan penelitian oleh [6] menggunakan metode geolistrik konfigurasi schlumberger yang bertujuan untuk mencari air tanah di Desa Muaro Pijoan, hasil yang didapatkan bahwa semua lintasan mengandung air tanah dengan rentang nilai 30-

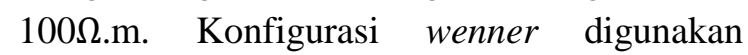
karena memiliki keunggulan pada ketelitian pembacaan potensial oleh elektroda potensial dan penyelidikan resistivitas pada posisi horizontal sehingga disebut juga metode resistivitas mapping.

\section{METODE}

Penelitian ini dilakukan pada suatu lahan kering di Desa Muaro Pijoan, Kecamatan Jambi Luar Kota, Kabupaten Muaro Jambi, Provinsi Jambi. Terdiri dari 5 lintasan, lintasan 1,2 dan 3 memiliki panjang 200 meter dengan spasi 10 meter dan lintasan 4 dan 5 memiliki panjang 100 meter dan spasi 5 meter.

\section{Peralatan Penelitian}

Peralatan yang digunakan dalam penelitian yaitu geo-soil resistivitymeter, elektroda, aki, meteran, palu, handy talky (HT), geo positioning system (GPS), palu, kabel penghubung, kabel roll, payung, kamera, datasheet, MS. Excel, software notepad, dan software Res2Dinv.

\section{Survei Lokasi Penelitian}

Survei lokasi penelitian bertujuan untuk mengetahui kondisi daerah yang di teliti mulai dari keadaan lahan, lingkungan, sumber air, koordinta geografis, elevasi, penentuan lintasan yang akan digunakan dan penentuan titik elektroda.

\section{Pengambilan Data}

Proses pengambilan data menggunakan seluruh peralatan yang digunakan. Data yang diambil berupa nilai arus listrik dan beda potensial digunakan untuk menentukan resistivitas bawah permukaan lokasi pengambilan datayang dicatat pada datasheet.

\section{Pengolahan Data}

Nilai arus dan potensial yang didapatkan pada pengambilan data diinput ke dalam ke Microsoft Excel untuk mendapatkan nilai hambatan, faktor geometri dan resistivitas semu. Kemudian input data kedalam Notepad 
sesuai urutan dan aturan yang telah ditetapkan untuk dapat dioleh software Res2Dinv. Data yang diolah menggunakan software Res2Dinv kemudian diinversi hingga didapatkan error $<25 \%$.

\section{Interpretasi Data}

Data yang diinterpretasi merupakan hasil pengolahan menggunakan software Res2Dinv berupa penampang 2 dimensi yang menggambarkan lapisan bawah permukaan. Setiap penampang diinterpretasi nilai resistivitas sebenarnya dengan membutuhkan data pendukung berupa data geologi dan data nilai resistivitas. Harga resistivitas digunakan untuk mengetahui jenis lapisan batuan yang mengandung air tanah di lokasi pengambilan data.

\section{HASIL DAN PEMBAHASAN}

\section{Lintasan 1}

Pengambilan data pada lintasan 1 dilakukan dengan panjang lintasan 200 meter dan spasi 10 meter yang terletak pada koordinat $01^{0} 35^{\prime}$ $44,8^{\prime \prime}$ LS $103^{0} 29$ ' 32,9" BT sampai $01^{0} 35^{\prime}$ 48,4 " LS $103^{0} 29$ ' 28, 1 " BT dan rata-rata ketinggian permukaan 29,57 meter di atas permukaan laut. Model inversi lintasan 1 memiliki kedalaman hingga 34,6 meter di bawah permukaan dengan nilai resistivitas antara 64,6-2.848 .m dan diperoleh nilai error sebesar 5,8\%.

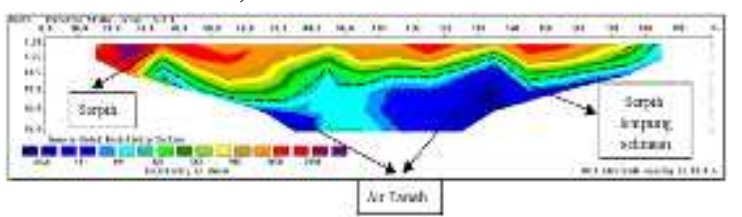

Gambar 1. Penampang resistivitas lintasan 1.

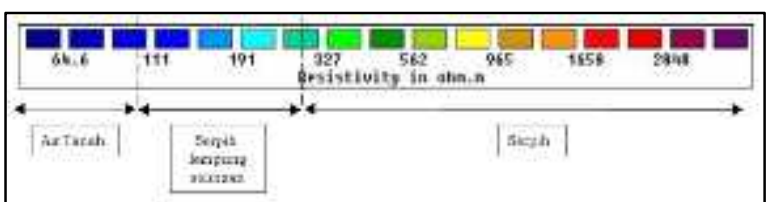

Gambar 2. Interpretasi Jenis Lapisan Batuan Lintasan 1.

Nilai resistivitas antara 64,6-100 .m diidentifikasi merupakan air tanah pada kedalaman 13,5-34,6 meter yang terbagi menjadi bagian kecil dan besar yang dipisahkan oleh lapisan serpih lempung selingan. Nilai resistivitas berkisar antara 100$300 . \mathrm{m}$ diidentifikasi merupakan lapisan serpih yang berselingan dengan lempung berada menyusup diantara bagian air tanah pada kedalaman 10-34,6 meter. Nilai resistivitas antara 300-2.848 .m diidentifikasi merupakan batuan serpih dengan rentang nilai 300-3.000 .m yang berada mulai dari kedalaman 2,5-10 meter.

Berdasarkan hasil interpretasi pada Gambar 1, terlihat bahwa air tanah terdapat dua bagian, bagian besar teletak pada kedalaman 13,5-34,6 meter di bawah permukaan dan terletak pada meter ke 100-170 di atas permukaan tanah. Sedangkan bagian kecil berada pada kedalaman 26,9-34,6 meter di bawah permukaan dan terletak pada meter ke $60-80$ di atas permukaan tanah. Lapisan serpih lempung selingan yang memiliki sifat impermeabel yaitu lapisan yang tidak dapat meloloskan air. Berdasarkan kedudukannya air tanah pada lintasan 1 merupakan air tanah dangkal.

\section{Lintasan 2}

Lintasan 2 terletak pada koordinat $01^{\circ} 35^{\prime}$ $44,0^{\prime \prime}$ LS $103^{0} 29^{\prime} 32,3$ " BT sampai $01^{0} 35^{\prime}$ 47,4 " LS $103^{\circ} 29$ ' 27,2" BT dengan panjang 200 meter dan spasi 10 meter. Rata-rata ketinggian permukaan tanah 29,1 meter diatas permukaan laut.

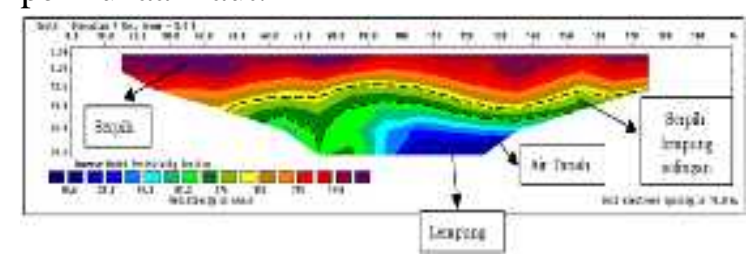

Gambar 3. Penampang resistivitas lintasan 2.

Model inversi lintasan 2 memiliki kedalaman 34,6 meter di bawah permukaan dengan nilai resistivitas antara 10,6-1.442 .m dan diperoleh nilai error sebesar 3,9\%. Berdasarkan gambar diatas, maka dapat diuraikan sebagai berikut: 


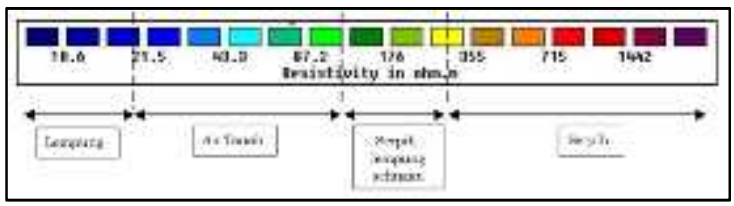

Gambar 4. Interpretasi jenis lapisan batuan lintasan 2.

Nilai resistivitas antara 10,6-20 .m diidentifikasi merupakan lempung. Nilai resistivitas antara 30-100 .m diidentifikasi merupakan air tanah. Nilai resistivitas antara 100-300 .m diidentifikasi merupakan batuan serpih yang berselingan dengan lempung. Nilai resistivitas antara 300-1.442 .m diidentifikasi merupakan batu serpih.

Berdasarkan hasil interpretasi pada Gambar 3, terlihat bahwa air tanah berada diantara lapisan lempung dan serpih lempung selingan yang berada pada kedalaman $\pm 17-30$ meter dan terletak pada meter ke 55-150. Berdasarkan kedudukannya air tanah pada lintasan 2 merupakan air tanah dangkal karena berada $<40$ meter di bawah permukaan.

\section{Lintasan 3}

Lintasan 3 terletak pada koordinat $01^{0} 35^{\prime}$ 43,4" LS $103^{0} 29$ ' 30,9" BT sampai $01^{0} 35$ ' 46,9” LS $103^{\circ} 29$ ' 26,1” BT dengan panjang 200 meter dan spasi 10 meter. Rata-rata ketinggian permukaan tanah 22 meter di atas permukaan laut.

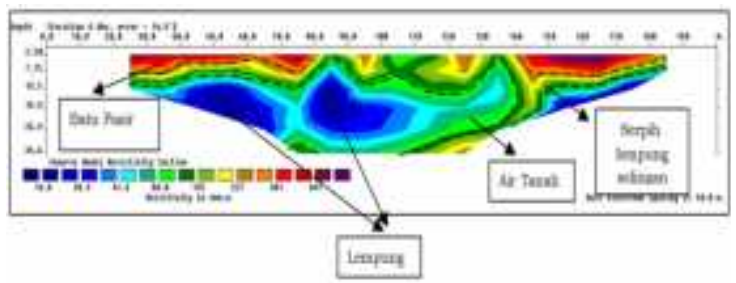

Gambar 5. Penampang resistivitas lintasan 3.

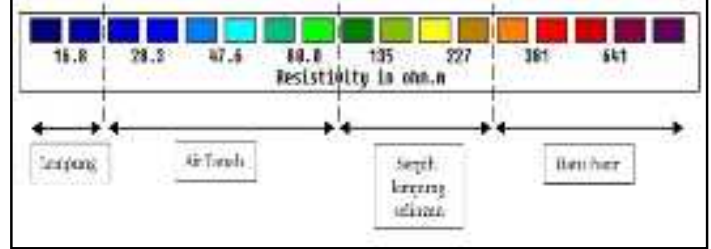

Gambar 6. Interpretasi jenis lapisan batuan lintasan 3.

Model inversi lintasan 3 memiliki kedalaman hingga 34,6 meter di bawah permukaan dengan nilai resistivitas antara
16,8-641 .m dan diperoleh nilai error sebesar 14,9\% dengan jumlah iterasi sebanyak 6 kali. Berdasarkan gambar diatas, maka dapat diuraikan sebagai berikut:

Nilai resistivitas berkisar antara 16,8-20

.m diidentifikasi merupakan lempung yang memiliki rentang nilai $2-20 \quad$.m. Nilai resistivitas berkisar antara 30-100 .m diidentifikasi merupakan air tanah. Nilai resistivitas berkisar antara 100-300 .m diidentifikasi merupakan lapisan serpih yang berselingan dengan lempung. Nilai resistivitas berkisar antara 300-641 m diidentifikasi merupakan batu pasir dan kerikil.

Berdasarkan hasil interpretasi pada Gambar 5 , terlihat bahwa air tanah dilingkupi oleh lapisan serpih lempung selingan dengan lapisan lempung berada diantara air tanah. Air tanah tampak paling dominan yang berada pada kedalaman 2,5-34,6 meter dan terdapat pada sepanjang lintasan. Berdasarkan kedudukannya air tanah pada lintasan 3 merupakan air tanah dangkal karena berada $<40$ meter di bawah permukaan.

\section{Lintasan 4}

Lintasan 4 terletak pada koordinat $01^{0} 35^{\prime}$ 45,4" LS $103^{0} 29^{\prime} 33,6$ " BT sampai $01^{0} 35$ ' 43,4 " LS $103^{0} 29^{\prime} 31,1$ " BT dengan panjang 100 meter dan spasi 5 meter. Rata-rata ketinggian permukaan tanah 31,05 meter di atas permukaan laut.

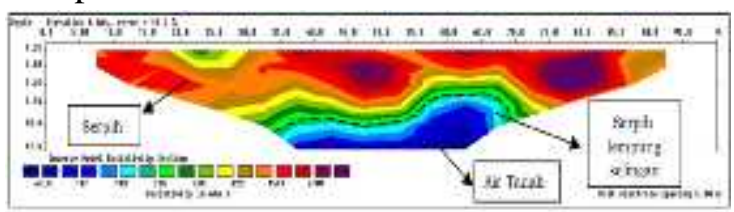

Gambar 7. Penampang resistivitas lintasan 4.

Model inversi lintasan 4 memiliki kedalaman hingga 17,3 meter di bawah permukaan dengan nilai resistivitas antara 62,4 $m$ dan 2.709 m.Terdapat error pada penampang lintasan 4 sebesar $16,2 \%$ dengan iterasi sebanyak 6 kali. Berdasarkan gambar diatas, maka dapat diuraikan sebagai berikut: 


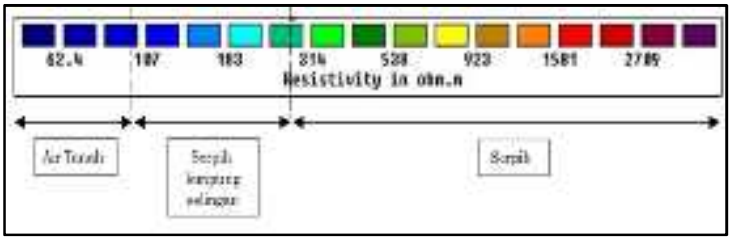

Gambar 8. Interpretasi jenis lapisan batuan lintasan 4.

Nilai resistivitas berkisar antara 62,4-100 $\mathrm{m}$ diidentifikasi merupakan air tanah. Nilai resistivitas berkisar antara 100-300 .m diidentifikasi merupakan batuan serpih yang berselingan dengan lempung. Nilai resistivitas berkisar antara 300-2.709 .m diidentifikasi merupakan batuan serpih.

Berdasarkan hasil interpretasi pada Gambar 7, terlihat bahwa air tanah berada di bawah lapisan serpih lempung selingan namun lapisan dibawah air tanah tidak terdeteksi karena keterbatasan konfigurasi yang digunakan. Lapisan serpih tampak dominan mulai dari kedalaman 1,25-13,4 meter di bawah permukaan. Air tanah tampak berada pada kedalaman $\pm 10-17,3$ meter dan terletak pada meter ke 35-65. Berdasarkan kedudukannya air tanah pada lintasan 4 merupakan air tanah dangkal karena berada <40 meter di bawah permukaan.

\section{Lintasan 5}

Lintasan 5 terletak pada koordinat $01^{0} 35^{\prime}$ 49,5" LS $103^{0} 29^{\prime} 28,1^{\prime \prime}$ BT sampai $01^{0} 35$ ' 46,4 " LS $103^{\circ} 29^{\prime} 27,1^{\prime \prime}$ BT dengan panjang 100 meter dan spasi 5 meter. Rata-rata ketinggian permukaan tanah 27,3 meter di atas permukaan laut.

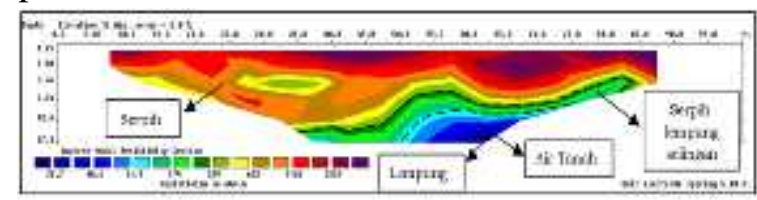

Gambar 9. Penampang resistivitas lintasan 5.

Gambar 18 memperlihatkan hasil pemetaan bawah permukaan sepanjang 100 meter. Model inversi lintasan 5 memiliki kedalaman hingga 17,3 meter di bawah permukaan dengan nilai resistivitas antara 25,7-2.225 .m. Terdapat error pada penampang lintasan 5 sebesar 6,8 $\%$ dengan iterasi sebanyak 12 kali.
Berdasarkan gambar diatas, maka dapat diuraikan sebagai berikut:

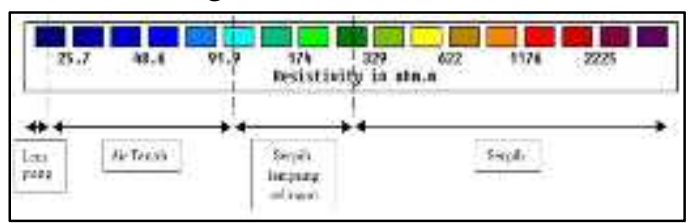

Gambar 10. Interpretasi jenis lapisan batuan lintasan 5 .

Nilai resistivitas berkisar $\leq 20 \quad . m$ diidentifikasi merupakan lempung. Nilai resistivitas berkisar antara 30-100 .m diidentifikasi merupakan air. Nilai resistivitas berkisar antara 100-300 .m diidentifikasi merupakan lapisan serpih yang berselingan dengan lempung. Nilai resistivitas berkisar antara $\quad 300-2.225 \quad . m$ diidentifikasi merupakan batuan serpih. Berdasarkan hasil interpretasi pada Gambar 9, terlihat bahwa air tanah berada diantara lapisan serpih lempung selingan dan lempung, namun lapisan lempung hanya terdeteksi sebagian karena keterbatasan konfigurasi yang digunakan. Lapisan serpih tampak dominan mulai dari kedalaman 1,25-15 meter di bawah permukaan. Air tanah tampak berada pada kedalaman $\pm 12-17,3$ meter dan terletak pada meter ke 50-75. Berdasarkan kedudukannya air tanah pada lintasan 5 merupakan air tanah dangkal karena berada $<40$ meter di bawah permukaan.

Secara umum, batuan penyusun yang ada di lokasi penelitian adalah, batu serpih, serpih berselingan dengan lempung, air tanah, lempung dan juga terdapat batu pasir. Dari 5 lintasan yang telah diinterpretasikan, semua lintasan memiliki potensi air tanah dengan nilai resistivitas 30-100 .m. Potensi terbesar dapat terlihat pada lintasan 3, dimana air tanah mendominasi lapisan batuan di bawah permukaan. Sedangkan potensi terkecil air tanah terlihat pada lintasan 5 dengan didominasi oleh batuan serpih. Letak air tanah untuk setiap lintasan masing-masing berada pada kedalaman 13,5 meter, 17 meter, 2,5 meter, 10 meter, dan 12 meter. Dilihat dari kedalaman air tanah pada semua lintasan, air tanah paling dalam berada pada lintasan 2 dan 
paling dangkal berada pada lintasan 3. Jika dilihat dari letak kedalamannya, kemungkinan air tanah terkumpul pada lintasan 2, karena letaknya yang paling dalam.

Daerah penelitian memiliki jenis air tanah dangkal yang berada <40 meter di bawah permukaan tanah. Hal ini dapat dibuktikan dari 2 buah sumur warga yang terdapat \pm 200 meter di dekat lokasi penelitian. Sumur pertama memiliki kedalaman 14 meter dengan tinggi permukaan air ke permukaan tanah \pm 12 meter dan sumur kedua memiliki kedalaman 1,5 meter dengan tinggi permukaan air ke permukaan tanah $95 \mathrm{~cm}$. Sumur pertama memiliki ketinggian 28 meter dari permukaan laut dan sumur kedua memiliki ketinggian 25 meter dari permukaan laut.

\section{KESIMPULAN}

Berdasarkan penelitian yang telah dilakukan dapat disimpulkan sebagai berikut: hasil pemetaan resistivitas bawah permukaan menggunakan konfigurasi wenner berupa model 2 dimensi dengan bentuk seperti perahu yang tergambar melalui citra warna yang memiliki nilai resistivitas. Rentang nilai resistivitas pada model 2 dimensi secara keseluruhan yaitu berkisar antara 10,6-2.848

.m. Adapun posisi air tanah bervariasi pada setiap lintasan, baik kedalaman maupun sebaran air tanah. Posisi air tanah secara berurutan yaitu berada pada kedalaman 13,5 meter, 2,5 meter, 13,5 meter, 10 meter, dan 12 meter di bawah permukaan. Potensi air tanah terbesar dan terkecil berada pada lintasan 3 dan lintasan 5 .

\section{SARAN}

Penelitian lebih lanjut disarankan untuk menggunakan konfigurasi selain schlumberger dan wenner untuk mengetahui perbedaan dari macam-macam konfigurasi terhadap nilai resistivitas dan pemodelan bawah permukaan. Selain itu disarankan untuk dapat dilakukan pemodelan 3 dimensi agar dapat dihitung debit dan volume air yang ada di bawah permukaan.

\section{DAFTAR PUSTAKA}

1. Sadjab, A. B., As'ari, \& Tanauma, A. (2012). Pemetaan Akuifer Air Tanah Di Sekitar Candi Prambanan Kabupaten Sleman Daerah Istimewa Yogyakarta Dengan Menggunakan Metode Geolistrik Tahanan Jenis. Jurnal MIPA UNSRAT Online, 1(1), 37-44.

2. Sutandi, M. C. (2012). Bahan Ajar Air Tanah. Universitas Kristen Maranatha: Bandung.

3. Todd, D. K. (2005). Groundwater Hydrology, $3^{\text {nd }}$ Edition. John Wiley \& Sons Inc: New York.

4. Reynolds, J. M. (1997). An Introduction to Applied and Environmental Geophysics. John Wiley \& Sons Inc: New York.

5. Khoiriyah, F. (2017). Pemanfaatan Metode Geofisika Resistivitas Konfigurasi Wenner untuk Menggambarkan Distribusi Resistivitas di Lahan Perkebunan Tebu pada Lahan Kering. Skripsi Universitas Jember: Jember.

6. Gultom, R. N. Susanti, \& Samsidar. (2017). Identifikasi Air Tanah di Desa Pijoan Kecamatan Jaluko Menggunakan Metode Geolistrik Konfigurasi Schlumberger. Jurnal Online of Physics, ISSN:2502-2016. 